\title{
The exploitation of Microbes: Next Generation Global Solution
}

\author{
Md. Asaduzzaman Shishir ${ }^{a}$ and Md. Mozammel Hoq ${ }^{b^{*}}$
}

Nature is a dynamic and complex system of continuous interactions among numerous biotic and abiotic components and the impacts of these interactions are sometimes perceived readily and sometimes at late (Dimkpa, Weinand, \& Asch, 2009; Meier et al., 2010). A good number of discoveries and inventions in medicine, agriculture or industry once renowned as very useful, turned into non-disposable problems. Of note, antibiotic resistance, carcinogenesis, pesticide resistance and adverse health effects, environmental pollution, disturbance of terrestrial and aquatic ecosystems, bioaccumulation and biomagnification, eutrophication, recalcitrance etc. and their chronic deleterious effects are few of the problems the world is facing and suffering continuously (Barai et al., 2017; Bonning, 2014; MacGowan \& Macnaughton, 2017; Patricia Herńandez-Martinez, Juan Ferŕe, \& Escriche, 2009; "Progress on antibiotic resistance," 2018; Shishir et al., 2014). In addition, the climatic and anthropogenic changes are bringing about adverse effects on the environment, agriculture and health globally (Bellard, Bertelsmeier, Leadley, Thuiller, \& Courchamp, 2012; Hoegh-Guldberg \& Bruno, 2010; Potter, Arthur Woods, \& Pincebourde, 2013; Taylor et al., 2013).

In solving these problems, holistic approaches coordinating sophisticated and state-of-the-art technologies from physical, chemical, computational and life sciences are being adopted. The developed countries have taken the advantages of recent maturation of technology in such cases especially with microbial biotechnology whereas the developing and least developed

Keywords: Microbial technology; Natural process; Artefacts; Ecofriendly solutions.

\section{Significance | Solving Global Problems with Next Generation Microbial Application}

*Correspondence: Md. Mozammel Hoq, PhD, Professor, Department of Microbiology, University of Dhaka, Dhaka-1000, Bangladesh. Contact no.: +8801717083673; E-mail: mhoq@du.ac.bd

Edited by Dr. Irwan Hanish Bin Warsanah, University Putra Malaysia, Malaysia. And accepted by the Editorial Board May 15, 2020 (received for review July 23, 2019) countries are still struggling and lagging behind miles (Ahasan \& Partanen, 2001; Kleinman, 2010; Lustick \& Zaman, 2011; Pickett, 2001). With the advent of sophisticated neoteric technologies and abstruse understandings in life science, even the very tiny lifethreatening portion of the total microbial world was transformed into the 'Goldmines' (Ahmad, Khan, Aqil, \& Singh, 2011; Barkay \& Schaefer, 2001; Dewapriya \& Kim, 2014; Mandal, Bolander, Mukhopadhyay, Sarkar, \& Mukherjee, 2006; J. N. S, Srinivasan, \& Devi, 2011; Vigneshvar, Sudhakumari, Senthilkumaran, \& Prakash, 2016). Microbes being harnessed by appropriate molecular techniques are the keys to this magic that took place in the last century. Due to the numerous exquisite attributes such as ubiquity and diversity, the ability of fast multiplication and adaptation, synthesis of diverse useful metabolites and biomolecules, the decomposing ability of diverse biological and chemical wastes, compatibility in genetic modification, the feasibility of industrial production and purification, and ecofriendly in nature, microorganisms were exploited successfully in diverse beneficial sectors and a lot more are still to come (Bakker, Manter, Sheflin, Weir, \& Vivanco, 2012; Claassens, Sousa, Dos Santos, De Vos, \& Van Der Oost, 2016; Löffler \& Edwards, 2006; Santero, Floriano, \& Govantes, 2016; Tender et al., 2002; Toribio-Mateas, 2018).

Since exploitation of the already established potentials of tiny microbes is yet to be attained at a minimum level by the developing and underdeveloped countries, sincere attention, appropriate planning and priority-based initiatives should be into these sectors. Developing and incorporating microbe based eco-friendly processes and agents in agriculture, health, environment, industry and so on would be the key in eradicating various nuisances and simultaneously boosting up the economy. The scopes are usually broad, and the working areas should be prioritized based on the countries' current as well as prognostic situations.

a Centre for Advanced Research in Sciences (CARS), University of Dhaka, Dhaka1000, Bangladesh

${ }^{b}$ Department of Microbiology, University of Dhaka, Dhaka-1000, Bangladesh

Please cite this article:

Shishir MA and Hoq MM (2020). The Exploitation of Microbes: Next Generation Global Solution. Microbial Bioactives, 3(1), 106-109. 
Countries dependent on agriculture should have a special focus on eco-friendly cultivation techniques with bio-fertilizer, plant growth-promoting rhizobacteria, bio-intensive crop protectants such as bio-pesticides, bio-herbicides, bio-fungicides and bacteriocins etc. Again, waste management involving biotransformation and bioconversion would facilitate the production of biofuel, biogas, compost. Frequent use of antibiotics in livestock, poultry and aquaculture should be replaced using efficient and indigenous probiotic organisms to minimize the emergence of antibiotic resistance. Often, the industries in these countries are the major sources of toxic chemical release due to the lack or inefficient effluent treatment plants (ETP). This problem should be solved pragmatically by incorporating heavy metal accumulating and degrading microorganisms (Gadd, 1990; Ilias, Rafiqullah, Debnath, Mannan, \& Mozammel Hoq, 2011) besides arranging required infrastructure in their facilities. Leather and textile industries, mostly situated in these countries, should involve microbe derived eco-friendly agents in different treatment steps of leathers and fabrics so that the environment, biodiversity and the public health are not at risk with harsh chemicals. Such agents are especially safer for their biodegradability and specificity and their synthesis is possible simply through the fermentation process. Therefore, screening, identification and characterization of potential microbes and developing bioprocess to produce them in large scale, should be prioritized for better management of the mentioned courses and strengthening the economy.

The pharmaceuticals are also leaning towards microbial world substituting the natural sources like plants, herbs or animals which have long been used in obtaining essential active ingredients. The limitations in productivity and recovery of active ingredients were solved with the appearance of recombinant DNA technology. Microbes are now being used as a unique biocatalyst for industriallevel production of useful metabolites. The compatibility of mass production of microbes in lesser space than that of plants and animals, functioning ability at mild temperature and pressure (thus saving energy), richness in diverse genes' pool that offer unlimited synthetic and degradative potentials and functioning as a suitable host for foreign genes etc. conferred them with tremendous advantages over the plants and animals (Bushell, 2003; Demain, 2014; Grossel, 1994; Hoq et al., 2013; Pandey, Soccol, Nigam, \& Soccol, 2000; Patra, Das, \& Shin, 2018; Sabra, Dietz, Tjahjasari, \& Zeng, 2010).Thus the growing demand for pharmaceutical products was met by the scientists exploiting microorganisms and many lifesaving drugs were developed, used and improved gradually. In succession, diverse bioactive compounds with antibacterial, antifungal, anti-viral, anti-algal, antioxidant, antifouling, anti-cancer and enzymatic activities were discovered and utilized in relevant sectors (Bérdy, 2005; Ferdous, Shishir, Khan, \& Hoq, 2018; Meena, Sharma, \& Kanwar, 2017; J. S \& Bharathi, 2018). In recent years, the successful discovery of novel bioactive compounds, especially from bacteria and fungi, has been attributed to the rapid development in advanced genetics, bioinformatics and computational biology, albeit with certain limitations in clinical and field trials (Adams \& Weiner, 2005; Biankin, Piantadosi, \& Hollingsworth, 2015; Demain, 2014; Fink \& Shaw Warren, 2014; van Belkum et al., 2018; Wackett, 2017; Watkins,
Stanton, Ryan, \& Ross, 2017). Developing countries can take the advantages of such traits of microbes, especially in their pharmaceutical sectors.

The tiny microbes with appropriate use would become the key components of every sphere of life. Hence, tremendous concerted efforts are required to utilize such a valuable resource that could be obtained from every inch of the world.

\section{Author contribution:}

MAS composed the manuscript. MMH broached the idea and directed in the composition of the manuscript and did the meticulous revision.

\section{Competing Interests}

Authors disclose no potential conflicts of interest.

\section{References:}

Adams, G. P., \& Weiner, L. M. (2005). Monoclonal antibody therapy of cancer. Nature Biotechnology, 23(9), 1147-1157.

https://doi.org/10.1038/nbt1137

Ahasan, M. R., \& Partanen, T. (2001). Occupational Health and Safety in the Least Developed Countries-A Simple Case of Neglect. Journal of Epidemiology, 11(2), 74-80. https://doi.org/10.2188/jea.11.74

Ahmad, I., Khan, M. S. A., Aqil, F., \& Singh, M. (2011). Microbial applications in agriculture and the environment: A broad perspective. In Microbes and Microbial Technology: Agricultural and Environmental Applications.

https://doi.org/10.1007/978-1-4419-7931-5_1

Bakker, M. G., Manter, D. K., Sheflin, A. M., Weir, T. L., \& Vivanco, J. M. (2012). Harnessing the rhizosphere microbiome through plant breeding and agricultural management. Plant and Soil.

https://doi.org/10.1007/s11104-012-1361-x

Barai, L., Saha, M. R., Rahman, T., Khandaker, T., Dutta, S., Hasan, R., \& Haq, J. A. (2017). Antibiotic resistance : Situation analysis in a tertiary care hospital of Bangladesh Original Article Antibiotic Resistance: Situation Analysis In a Tertiary Care Hospital of Bangladesh, 34(December), 15-19.

Barkay, T., \& Schaefer, J. (2001). Metal and radionuclide bioremediation: issues, considerations and potentials. Current Opinion in Microbiology, 4(3), 318-323.

https://doi.org/10.1016/S1369-5274(00)00210-1

Bellard, C., Bertelsmeier, C., Leadley, P., Thuiller, W., \& Courchamp, F. (2012). Impacts of climate change on the future of biodiversity. Ecology Letters, 15(4), 365-377. https://doi.org/10.1111/j.1461-0248.2011.01736.x

Bérdy, J. (2005). Bioactive Microbial Metabolites. The Journal of Antibiotics, 58(1), 1-26. https://doi.org/10.1038/ja.2005.1

Bérdy, J. (2012). Thoughts and facts about antibiotics: Where we are now and where we are heading. Journal of Antibiotics. https://doi.org/10.1038/ja.2012.27

Biankin, A. V., Piantadosi, S., \& Hollingsworth, S. J. (2015). Patient-centric trials for therapeutic development in precision oncology. Nature, 526(7573), 361-370. https://doi.org/10.1038/nature15819

Bonning, B. C. (2014). Bt Toxin Modification for Enhanced Efficacy, 3005-3027. https://doi.org/10.3390/toxins6103005

Bushell, M. (2003). Manual of industrial microbiology and biotechnology. Enzyme and Microbial Technology.

https://doi.org/10.1016/0141-0229(87)90013-5

Claassens, N. J., Sousa, D. Z., Dos Santos, V. A. P. M., De Vos, W. M., \& Van Der Oost, J.

(2016). Harnessing the power of microbial autotrophy. Nature Reviews Microbiology. https://doi.org/10.1038/nrmicro.2016.130 
Demain, A. L. (2014). Importance of microbial natural products and the need to revitalize their discovery. Journal of Industrial Microbiology \& Biotechnology, 41(2), 185-201. https://doi.org/10.1007/s10295-013-1325-z

Dewapriya, P., \& Kim, S. (2014). Marine microorganisms: An emerging avenue in modern nutraceuticals and functional foods. Food Research International, 56, 115-125. https://doi.org/10.1016/j.foodres.2013.12.022

Dimkpa, C., Weinand, T., \& Asch, F. (2009). Plant-rhizobacteria interactions alleviate abiotic stress conditions. Plant, Cell \& Environment, 32(12), 1682-1694.

https://doi.org/10.1111/j.1365-3040.2009.02028.x

Ferdous, U. T., Shishir, M. A., Khan, S. N., \& Hoq, M. M. (2018). Bacillus spp.: Attractive Sources of Anti-cancer and Anti-proliferative Biomolecules. Microbial Bioactives, 1(1), E033-E045.

https://doi.org/10.25163/microbbioacts.11005B0408130818

Fink, M. P., \& Shaw Warren, H. (2014). Strategies to improve drug development for sepsis. Nature Reviews Drug Discovery.

https://doi.org/10.1038/nrd4368

Gadd, G. M. (1990). Heavy metal accumulation by bacteria and other microorganisms Experientia, 46(8), 834-840.

https://doi.org/10.1007/BF01935534

Grossel, S. S. (1994). Safety in industrial microbiology and biotechnology. Journal of Loss Prevention in the Process Industries.

https://doi.org/10.1016/0950-4230(94)80080-4

Hoegh-Guldberg, O., \& Bruno, J. F. (2010). The Impact of Climate Change on the World's Marine Ecosystems. Science, 328(5985), 1523-1528.

https://doi.org/10.1126/science.1189930

Hoq, M. M., Mamun, A. Al, Shishir, M. A., Akand, N. R., Khan, M., \& Khan, S. N. (2013). Bioprocess development for eco-friendly microbial products and its impacts on bioindustry establishment in bangladesh. In International Conference on Biotechnology (Vol.1, pp.205-217). Dhaka, Bangladesh.: cares.org.bd. Retrieved from

http://www.caresbd.org/uploads/book1_14.pdf

Ilias, M., Rafiqullah, I. M., Debnath, B. C., Mannan, K. S. Bin, \& Mozammel Hoq, M. (2011) Isolation and Characterization of Chromium(VI)-Reducing Bacteria from Tannery Effluents. Indian Journal of Microbiology, 51(1), 76-81.

https://doi.org/10.1007/s12088-011-0095-4

Kleinman, A. (2010). Four social theories for global health. The Lancet, 375(9725), 15181519.

https://doi.org/10.1016/S0140-6736(10)60646-0

Löffler, F. E., \& Edwards, E. A. (2006). Harnessing microbial activities for environmental cleanup. Current Opinion in Biotechnology, 173), 274-284.

https://doi.org/10.1016/j.copbio.2006.05.001

Lustick, D. R., \& Zaman, M. H. (2011). Biomedical engineering education and practice challenges and opportunities in improving health in developing countries. In 2011 Atlanta Conference on Science and Innovation Policy (pp.1-5). IEEE.

https://doi.org/10.1109/ACSIP.2011.6064477

MacGowan, A., \& Macnaughton, E. (2017). Antibiotic resistance. Medicine, 45(10), 622 628.

https://doi.org/10.1016/j.mpmed.2017.07.006

Mahlapuu, M., Håkansson, J., Ringstad, L., \& Björn, C. (2016). Antimicrobial Peptides: An Emerging Category of Therapeutic Agents. Frontiers in Cellular and Infection Microbiology.

https://doi.org/10.3389/fcimb.2016.00194

Mandal, D., Bolander, M. E., Mukhopadhyay, D., Sarkar, G., \& Mukherjee, P. (2006). The use of microorganisms for the formation of metal nanoparticles and their application. Applied Microbiology and Biotechnology.

https://doi.org/10.1007/s00253-005-0179-3

Meena, K. R., Sharma, A., \& Kanwar, S. S. (2017). Microbial Lipopeptides and their Medical Applications. Annals of Pharmacology and Pharmaceutics, 2(21), 1-5.

Meier, E. S., Kienast, F., Pearman, P. B., Svenning, J. C., Thuiller, W., Araújo, M. B., ...
Zimmermann, N. E. (2010). Biotic and abiotic variables show little redundancy in explaining tree species distributions. Ecography.

https://doi.org/10.1111/j.1600-0587.2010.06229.x

Pandey, A., Soccol, C. R., Nigam, P., \& Soccol, V. T. (2000). Biotechnological potential of agro-industrial residues. I: Sugarcane bagasse. Bioresource Technology.

https://doi.org/10.1016/S0960-8524(99)00142-X

Patra, J. K., Das, G., \& Shin, H. S. (2018). Microbial Biotechnology. (J. K. Patra, G. Das, \& H.-

S. Shin, Eds.), Microbial Biotechnology. Singapore: Springer Singapore.

https://doi.org/10.1007/978-981-10-7140-9

Patricia Herńandez-Martinez, Juan Ferŕe, \& Escriche, B. (2009). Broad-spectrum crossresistance in Spodoptera exigua from selection with a marginally toxic Cry protein. Pest Management Science, 65(6), 645-650.

https://doi.org/10.1002/ps.1725

Pickett, K. E. (2001). Multilevel analyses of neighbourhood socioeconomic context and health outcomes: a critical review. Journal of Epidemiology \& Community Health, 55(2), 111-122.

https://doi.org/10.1136/jech.55.2.111

Potter, K. A., Arthur Woods, H., \& Pincebourde, S. (2013). Microclimatic challenges in global change biology. Global Change Biology.

https://doi.org/10.1111/gcb.12257

Progress on antibiotic resistance. (2018). Nature, 562(7727), 307-307.

https://doi.org/10.1038/d41586-018-07031-7

S, J., \& Bharathi, V. (2018). Bioactive potential from Marine sponge Callyspongia diffusa associated Pseudomonus fluorescens BCPBMS-1 and Penicillum citrinum. Microbial Bioactives, 1(1), 8-13.

S, J. N., Srinivasan, V. M., \& Devi, C. S. (2011). Novel anti-cancer compounds from marine actinomycetes : A Review. Industrial Biotechnology.

Sabra, W., Dietz, D., Tjahjasari, D., \& Zeng, A.-P. (2010). Biosystems analysis and engineering of microbial consortia for industrial biotechnology. Engineering in Life Sciences, 195), 407-421.

https://doi.org/10.1002/elsc.201000111

Santero, E., Floriano, B., \& Govantes, F. (2016). Harnessing the power of microbial metabolism. Current Opinion in Microbiology, 31, 63-69.

https://doi.org/10.1016/j.mib.2016.03.003

Shishir, A., Roy, A., Islam, N., Rahman, A., Khan, S. N., \& Hoq, M. M. (2014). Abundance and diversity of Bacillus thuringiensis in Bangladesh and their cry genes profile. Frontiers in Environmental Science, 2(June), 20. https://doi.org/10.3389/fenvs.2014.00020

Taylor, R. G., Scanlon, B., Döll, P., Rodell, M., Van Beek, R., Wada, Y., ... Treidel, H. (2013) Ground water and climate change. Nature Climate Change.

https://doi.org/10.1038/nclimate1744

Tender, L. M., Reimers, C. E., Stecher, H. A., Holmes, D. E., Bond, D. R., Lowy, D. A., ... Lovley, D. R. (2002). Harnessing microbially generated power on the seafloor. Nature Biotechnology.

https://doi.org/10.1038/nbt716

Toribio-Mateas, M. (2018). Harnessing the Power of Microbiome Assessment Tools as Part of Neuroprotective Nutrition and Lifestyle Medicine Interventions. Microorganisms. https://doi.org/10.3390/microorganisms6020035

van Belkum, A., Bachmann, T. T., Lüdke, G., Lisby, J. G., Kahlmeter, G., Mohess, A., ... Dunne, W. M. (2018). Developmental roadmap for antimicrobial susceptibility testing systems. Nature Reviews Microbiology.

https://doi.org/10.1038/s41579-018-0098-9

Vigneshvar, S., Sudhakumari, C. C., Senthilkumaran, B., \& Prakash, H. (2016). Recent Advances in Biosensor Technology for Potential Applications - An Overview. Frontiers in Bioengineering and Biotechnology.

https://doi.org/10.3389/fbioe.2016.00011

Wackett, L. P. (2017). Microbial therapeutics. Microbial Biotechnology, 103), 666-667. https://doi.org/10.1111/1751-7915.12724

Watkins, C., Stanton, C., Ryan, C. A., \& Ross, R. P. (2017). Microbial Therapeutics Designed 
for Infant Health. Frontiers in Nutrition, 4(October), 1-8.

https://doi.org/10.3389/fnut.2017.00048

Submit your next manuscript to Microbial Bioactives

published by EMAN Research

- Convenient online submission

- Thorough peer review

- No space constraints or color figure charges

- Immediate publication on acceptance

- Inclusion in Australian National Libraray and Google Scholar

- Both Open (80-100\% subsidized APC by ER) \& non-open access option

Submit your manuscript at

https://microbialbioactives.emanresearch.org 